\title{
ANALISIS KESIAPAN BELAJAR DARING SISWA KELAS VII PADA MASA PANDEMI COVID-19 DI DESA SIMPANG TIGA LAEBINGKE KECAMATAN SIRANDORUNG
}

\author{
Oleh : \\ Holong Sumurung Siagian ${ }^{1)}$, Tamin Ritonga ${ }^{2)}$, Roslian Lubis ${ }^{3)}$ \\ ${ }^{1,3}$ Fakultas MIPA, Institut Pendidikan Tapanuli Selatan \\ ${ }^{2}$ Fakultas IPSB, Institut Pendidikan Tapanuli Selatan
}

\begin{abstract}
Abstrak
Tujuan penelitian ini adalah untuk mendeskripsikan kesiapan siswa dalam pembelajaran online pada siswa kelas VII di Simpang Tiga Laebingke Kecamatan Sirandorung. Pendekatan penelitian menggunakan deskriptif kualitatif. Triangulasi digunakan untuk memeriksa keabsahan data dengan menggunakan angket (skala Guttman), observasi, dan wawancara (untuk siswa dan guru Matematika) dalam pengumpulan data. Hasil penelitian menunjukkan 1) berdasarkan angket menunjukkan rata-rata kesiapan siswa dalam belajar online adalah 65,33 (kategori kurang), 2) berdasarkan wawancara menunjukkan siswa memiliki kategori kurang kesiapan siswa dalam belajar online, dan 3) berbasis hasil observasi menunjukkan kesiapan siswa dalam pembelajaran online termasuk kategori kurang.
\end{abstract}

Kata kunci: kesiapan siswa, pembelajaran, online

\section{Abstract}

The aim of this study is to describe students' readiness in learning online at seventh grade students in Simpang Tiga Laebingke, Sirandorung sub-district. The approach of the research used qualitative descriptive. Triangulation was used in checking data validity by using questionnaire (Guttman scale), observation, and interview (for students and Mathematics teacher) in collecting the data. The result of the research shows 1) based on questionnaire shows the average of students' readiness in learning online is 65.33 (poor category), 2) based on interview shows the students have poor category students' readiness in learning online, and 3) based on observation shows the students have poor category students' readiness in learning online.

Key words: students' readiness, learning, online

\section{PENDAHULUAN}

Pendidikan merupakan proses usaha secara sadar yang dilakukan oleh pendidik dan peserta didik untuk dapat mengembangkan potensi sehingga dapat mencapai tujuan yang diinginkan. Tujuan dari suatu pendidikan tercantum dalam Undang-Undang RI No.20 Tahun 2003 tentang Sistem Pendidikan Nasional Bab II pasal 3 yaitu mengembangkan potensi peserta didik agar menjadi manusia yang beriman dan bertaqwa kepada Tuhan Yang Maha Esa, berakhlak mulia, sehat, berilmu, cakap, kreatif, mandiri, dan menjadi warga negara yang demokratis serta bertanggung jawab. Dengan demikian untuk mencapai tujuan pendidikan yang diharapkan maka proses pembelajaran diharapkan dapat berjalan dengan lancar. Pembelajaran pada kurikulum 2013 atau K13 yang berlaku saat ini mengarahkan peserta didik untuk mampu berpikir kritis, mendorong kreativitas peserta didik sehingga dapat disimpulkan bahwa pembelajaran pada K13 adalah pembelajaran berpusat pada siswa.

Pembelajaran pada kurikulum 2013 saat ini yang berpusat pada siswa bukan lagi guru diharapkan siswa mampu menjadi pelajar yang mandiri sepanjang hayat artinya proses-proses belajar di kelas mampu membentuk siswa yang bersangkutan menjadi pribadi yang memiliki kemampuan untuk membelajarkan dirinya pada situasi dan konteks yang berkembang di kemudian hari. Hal ini menunjukkan pentingnya kesiapan belajar dari siswa.

Kesiapan belajar merupakan suatu kondisi seseorang yang telah siap untuk melakukan suatu kegiatan proses pembelajaran. Namun yang menjadi persoalan saat ini adalah pembelajaran tidak dapat dilaksanakan seperti biasanya yaitu tatap muka melainkan pembelajaran daring. 
Pendidikan secara tatap muka tidak dapat dilaksanakan akibat wabah suatu penyakit yang menyebar disebabkan oleh virus bernama corona atau lebih dikenal dengan istilah covid19 (Corona Virus Diseases-19). Dengan adanya virus COVID-19 di Indonesia saat ini berdampak bagi seluruh masyarakat. Dampak virus COVID-19 terjadi diberbagai bidang seperti sosial, ekonomi, pariwisata dan pendidikan. Surat Edaran (SE) yang dikeluarkan Pemerintah pada 18 Maret 2020 segala kegiatan didalam dan diluar ruangan di semua sektor sementara waktu ditunda demi mengurangi penyebaran corona terutama pada bidang pendidikan. Pada tanggal 24 maret 2020 Menteri Pendidikan dan Kebudayaan Republik Indonesia mengeluarkan Surat Edaran Nomor 4 Tahun 2020 Tentang Pelaksanaan Kebijakan Pendidikan Dalam Masa Darurat Penyebaran COVID dan SE Sesjen nomor 15 tahun 2020 tentang Pedoman Pelaksanaan BDR selama darurat Covid-19. Dalam Surat Edaran tersebut dijelaskan bahwa proses belajar dilaksanakan di rumah melalui pembelajaran daring/jarak jauh dilaksanakan untuk memberikan pengalaman belajar yang bermakna bagi siswa. Belajar di rumah dapat difokuskan pada pendidikan kecakapan hidup antara lain mengenai pandemi Covid-19, (Kemdikbud, 2020).

Pembelajaran daring merupakan pemanfaatan jaringan internet dalam proses pembelajaran. Dengan pembelajaran daring siswa memiliki keleluasaan waktu belajar, dapat belajar kapanpun dan dimanapun. Siswa dapat berinteraksi dengan guru menggunakan beberapa aplikasi seperti classroom, video converence, telepon atau live chat, zoom maupun melalui Whatsapp Group. Pembelajaran ini merupakan inovasi pendidikan untuk menjawab tantangan akan ketersediaan sumber belajar yang variatif dan solusi terhadap pembatasan sosial yang dilakukan oleh pemerintah.

Kesiapan belajar dapat diperoleh siswa jika siswa tersebut mampu dan telah memiliki suatu cara yang dapat membuatnya untuk memberikan respon terhadap kegiatan pembelajaran. Adanya kesiapan akan mendorong untuk melakukan suatu respon dengan cara-cara tertentu untuk melakukan sesuatu, baik berupa individu ataupun objek tertentu.

Berdasarkan uraian di atas pembelajaran daring dapat diterapkan dengan memanfaatkan berbagai fasilitas aplikasi pembelajaran menuntut kesiapan siswa dalam pembelajaran agar para siswa tidak ketinggalan pelajaran selama pembelajaran jarak jauh atau daring. Dengan demikian penulis tertarik melakukan penelitian dengan judul penelitian "Analisis Kesiapan Belajar Daring Siswa Kelas VII Pada Masa Pandemi COVID-19 di Desa Simpang Tiga Laebingke Kecamatan Sirandorung".

\section{Pengertian Kesiapan}

Kesiapan adalah suatu keadaan bersiap-siap untuk mempersiapkan sesuatu. Kesiapan merupakan sikap siap untuk melaksanakan dan mampu melaksanakan suatu pekerjaan. Menurut Slameto (2012: 113) menyatakan bahwa "Kesiapan adalah keseluruhan kondisi seseorang yang membuatnya siap untuk memberi respon/jawaban dengan cara tertentu terhadap suatu situasi”.

Berdasarkan uraian di atas dapat disimpulkan bahwa kesiapan adalah tingkat perkembangan diri kematangan atau kedewasaan yang menguntungkan untuk mempraktikan sesuatu. Kesiapan juga merupakan suatu kondisi dimana tingkat kedewasaan atau kematangan seseorang siap untuk melakukan atau mempraktikkan sesuatu.

\section{Pengertian Belajar}

Kegiatan belajar dalam proses pendidikan di sekolah merupakan kegiatan yang paling pokok. Belajar merupakan suatu proses usaha yang dilakukan seseorang untuk memperoleh suatu perubahan tingkah laku yang baru. Riyanto (2009:6), "Belajar adalah suatu proses untuk mengubah informasi yang tidak terbatas pada keterampilan tetapi juga meliputi fungsi-fungsi, seperti skill, persepsi, emosi, proses berfikir sehingga dapat menghasilkan perbaikan performasi”. Selanjutnya

\section{Kesiapan Belajar}

Kesiapan dalam belajar merupakan gambaran kondisi dimana siswa sudah siap untuk melakukan aktivitas belajar dengan penuh kesadaran untuk memperoleh pengetahuan, pemahaman, keterampilan, sikap dengan cara mengamati, meniru, latihan serta masuknya pengalaman baru pada siswa. Slameto (2012:113) menyatakan bahwa "kesiapan belajar adalah keseluruhan kondisi seseorang yang membuatnya siap untuk memberi jawaban di dalam cara tertentu terhadap situasi. Hal ini berarti bahwa kesiapan belajar merupakan sikap siap yang dimiliki seseorang untuk menerima situasi tertentu, dalam hal ini yang berkaitan dengan belajar". 


\section{Aspek Kesiapan Belajar Siswa}

Dalam pembelajaran suatu kondisi siswa dikatakan siap setidak-tidaknya mencakup beberapa aspek, menurut Slameto (2012:14), “Ada tiga aspek yang mempengaruhi kesiapan yaitu: 1) Kondisi fisik, mental, dan emosional 2) Kebutuhan atau motif tujuan 3) Keterampilan, pengetahuan, dan pengertian yang lain yang telah dipelajari”.

\section{Faktor yang Mempengaruhi Siswa Dalam Belajar}

Secara umum faktor-faktor yang memengaruhi belajar dibedakan atas dua kategori, yaitu faktor internal dan faktor eksternal. Kedua faktor tersebut saling memengaruhi dalam proses belajar individu sehingga menentukan kualitas hasil belajar. Muhibbin (2011:45) merumuskan beberapa faktor-faktor yang mempengaruhi hasil belajar sebagai berikut:

1. Faktor internal (faktor dari dalam siswa), yakni keadaan / kondisi jasmani dan rohani siswa.

2. Faktor eksternal (faktor dari luar diri siswa), yakni kondisi lingkungan sekitar siswa;

3. Faktor pendekatan belajar (approach to learning), yakni jenis upaya belajar siswa yang meliputi strategi dan metode yang digunakan untuk melakukan kegiatan pembelajaran materi-materi pelajaran.

\section{METODOLOGI}

Penelitian ini dilakukan di Desa Simpang Tiga Laebingke Kecamatan Sirandorung. Metode penelitian adalah tata cara yang digunakan dalam melaksanakan penelitian untuk mencari jawaban dan pemecahan masalah. Sugiyono (2011:3) juga menyatakan: "Secara umum metode penelitian diartikan sebagai cara ilmiah untuk mendapatkan data dengan tujuan dan kegunaan tertentu".

\section{a. Objek dan Informan Penelitian}

Informan penelitian merupakan orang yang dimanfaatkan untuk memberikan informasi terkait permasalahan penelitian yang dikaji. Sejalan dengan itu Bungin (2012:111) berpendapat bahwa, "Informan adalah orang yang diperkirakan menguasai dan memahami data, informasi, ataupun fakta dari suatu objek penelitian." Peneliti menetapkan informan yaitu sebanyak lima siswa kelas VII di Desa Simpang Tiga Laebingke Kecamatan Sirandorung dan Guru Matematika di Desa Simpang Tiga Laebingke Kecamatan Sirandorung.

\section{b. Data dan Sumber Data} sekunder.

Sumber data dalam penelitian ini di bagi menjadi sumber data primer dan sumber data

\section{c. Teknik Pengumpulan Data}

Untuk memperoleh data yang dikehendaki sesuai dengan permasalahan dalam penelitian ini, maka penulis menggunakan teknik observasi, angket, wawancara dan dokumentasi.

1) Observasi, merupakan pengamatan yang dilakukan peneliti untuk mendapatkan informasi yang dibutuhkan oleh peneliti terkait permasalahan yang sedang dikaji. Pada observasi ini, peneliti mengamati tentang proses pembelajaran daring siswa di desa Simpang Tiga Laebingke Kecamatan Sirandorung.

2) Angket merupakan sejumlah pertanyaan tertulis yang diberikan kepada responden untuk menggali informasi dan data terkait masalah penelitian yang sedang dikaji. Adapun kisikisi angket yang akan diberikan adalah sebagai berikut:

Tabel 1

Kisi-Kisi Angket Kesiapan Siswa Dalam Pembelajaran Daring Pada Masa Pandemi

\begin{tabular}{clcc}
\hline No & Langkah-Langkah & Nomor Item & Jumlah \\
\hline 1 & Kesiapan Fisik & $1,2,3,4,5$ & 5 \\
\hline 2 & Kesiapan Psikis & $6,7,8,9,10$ & 5 \\
\hline 3 & Kesiapan Materiil & $11,12,13,14,15$ & 5 \\
\hline & Jumlah & $\mathbf{1 5}$ & \\
\hline
\end{tabular}

Adapun penskoran yang digunakan dalam penelitian ini adalah sesuai rumus berikut:

Nilai Akhir $=\frac{\text { Jumlah skor yang diperoleh }}{\text { Jumlah skor maksimal }} \times 100 \%$ 
JURNAL MathEdu (Mathematic Education Journal) http://journal.ipts.ac.id/index.php/MathEdu

Tabel 2

Klasifikasi Penilaian Hasil Angket Kesiapan Siswa Dalam Pembelajaran Daring Pada Masa Pandemi

\begin{tabular}{ccc}
\hline No & Interval & Interprestasi \\
\hline 1 & $80-100$ & Sangat Siap \\
\hline 2 & $70-79$ & Siap \\
\hline 3 & $60-69$ & Cukup Siap \\
\hline 4 & $50-59$ & Tidak Siap \\
\hline 5 & $0-49$ & Sangat Tidak Siap \\
\hline
\end{tabular}

Sumber: Muhibbin Syah (2011:111)

3) Wawancara atau kuesionar lisan adalah dialog yang dilakukan oleh pewawancara untuk memperoleh informasi dari terwawancara. Dalam penelitian ini teknik wawancara peneliti menggali informasi secara mendalam dari informan mengenai bagaimana kesiapan siswa dalam pembelajaran daring dengan wawancara langsung kepada informan.

4) Dokumentasi adalah metode pengumpulan data yang datanya diperoleh dari buku, internet, atau dokumen lain yang menunjang penelitian yang dilakukan. Dokumen merupakan catatan mengenai peristiwa yang sudah berlalu. Peneliti mengumpulkan dokumen yang dapat berupa tulisan, gambar, buku, jurnal dan dokumen lainnya.

Teknik menjamin keabsahan data digunakan untuk memastikan kebenaran dari data yang diperoleh. Teknik yang digunakan untuk menjamin keabsahan data adalah trianggulasi.

\section{d. Teknik Analisis Data}

Analisis data merupakan langkah yang terpenting untuk memperoleh temuan-temuan hasil penelitian. Analisis data yaitu proses pengumpulan data agar dapat ditafsirkan. Analisis data dilakukan pada saat mengumpulkan data dan setelah pengumpulan data. Proses analisis data dimulai dengan menelaah seluruh data yang tersedia dari berbagai sumber, yaitu dari wawancara, observasi, yang sudah dituliskan dalam catatan lapangan, dokumen resmi, gambar, foto, dan sebagainya. Ada tiga kegiatan yang dilakukan dalam melakukan analisis data diantaranya dengan:

1. Data reduction (reduksi data)

Tahap ini merupakan proses pemilihan, pemusatan perhatian, pengabstraksian dan mentransformasikan data kasar yang diambil dari lapangan. Inti dari reduksi data adalah proses penggabungan dan penyeragaman segala bentuk data menjadi bentuk tulisan yang akan dianalisis.

2. Data display (penyajian data)

Setelah data-data tersebut terkumpul kemudian peneliti mengelompokkan hal-hal yang serupa menjadi kategori atau kelompok-kelompok agar peneliti lebih mudah untuk melakukan pengambilan kesimpulan.

3. Conclusion drawing (penarikan kesimpulan)

Pada tahap ini, peneliti membandingkan data-data yang sudah didapat dengan data-data hasil wawancara dengan subjek dan informan yang bertujuan untuk menarik kesimpulan.

\section{HASIL PENELITIAN DAN PEMBAHASAN}

Gambaran Hasil Angket Kesiapan Belajar Daring Siswa Kelas VII Pada Masa Pandemi Covid-19 di Desa Simpang Tiga Laebingke Kecamatan Sirandorung

Sesuai hasil penelitian yang dilakukan diketahui hasil angket yang diberikan kepada sekitar 5 siswa kelas VII di Desa Simpang Tiga Laebingke untuk melihat kesiapan dalam pembelajaran daring sebagai berikut:

Tabel 4.3

Keadaan Pendudukan Desa Simpang Tiga Laebingke Tahun 2020

\begin{tabular}{|c|l|c|c|}
\hline No & Aspek yang diamati & Rata- rata & Kategori \\
\hline 1 & Kesiapan Fisik & 64 & Kurang siap \\
\hline 2 & Kesiapan Psikis & 56 & Kurang Siap \\
\hline 3 & Kesiapan Materiil & 48 & Kurang Siap \\
\hline \multicolumn{2}{|c|}{ Nilai Rata-rata Keseluruhan } & $\mathbf{6 5 . 3 3}$ & Kurang Siap \\
\hline
\end{tabular}


Berdasarkan hasil data yang di kumpulkan di atas di peroleh nilai rata-rata keseluruhan dari angket diperoleh nilai rata-rata sebesar $65.33 \%$ dengan kategori kurang. Selanjutnya dari hasil angket yang dibagikan diketahui bahwa kesiapan fisik siswa diperoleh nilai rata-rata sebesar 64\% dengan kategori cukup yang berarti kesiapan fisik siswa dalam pembelajaran daring. Kemudian kesiapan psikis siswa diperoleh nilai rata-rata angket sebesar 56\% pada kategori kurang yang berarti pelaksanaan pembelajaran daring siswa memiliki psikis yang kurang baik. Selanjutnya kesiapan materiil siswa diketahui nilai rata-rata hasil angket sebesar $48 \%$ yakni berada pada kategori kurang.

Kemudian dari hasil penelitian diketahui Dimana KS memperoleh skor 80 dengan kategori sangat siap. WT memperoleh skor sebesar 60 dengan kategori cukup siap. NH memperoleh skor sebesar 53.33 dengan kategori sangat tidak siap. JSS memperoleh skor sebesar 33.33 dengan kategori sangat tidak siap. EAS memperoleh skor sebesar 53.33 dengan kategori sangat tidak siap.

\section{Hasil Wawancara Kesiapan Belajar Daring Siswa Kelas VII Pada Masa Pandemi Covid-19 Di Desa Simpang Tiga Laebingke Kecamatan Sirandorung}

Pengumpulan data dalam penelitian ini juga menggunakan wawancara. Pelaksanaan wawancara dalam penelitian ini bertujuan untuk mengetahui bagaimana kesiapan belajar daring siswa di kelas VII di Desa Simpang Tiga Laebingke Kecamatan Sirandorung pada tiga aspek yaotu kesiapan fisik, kesiapan psikis dan kesiapan materiil. Peneliti dalam melakukan pengumpulan data dengan cara mewawancarai sebanyak 5 siswa kelas VII yang berdomisili di Desa impang Tiga Laebingke Kecamatan Sirandorung. Pelaksanaan penelitian dengan cara wawancara peneliti tetap menerapkakn protokol kesehatan. adapun hasil wawancara dapat dilihat sebagai berikut:

\section{Kesiapan Fisik}

Dari hasil wawancara yang dilakukan diketahui siswa merasa kewalahan dan siswa tidak siap secara fisik dalam pembelajaran daring. Bayaknya tugas, kendala jaringan dan juga dalam pembelajaran terkadang membutuhkan waktu berjam-jam karena pembelajaran daring fleksibel membuat para siswa mudah lelah dan bahwa ada siswa yang sakit.

Keadaan fisik ini meliputi kesiapan siswa baik secara siap dengan badan yang sehat seperti indera dan kondisi stamina yang baik dalam mengikuti pembelajaran daring. Seperti halnya pendapat Slameto (2012:113) menyatakan bahwa "kondisi fisik meliputi kondisi fisik temporer (lelah, keadaan, dan alat indra) dan yang permanen (cacat tubuh)". Sesuai dengan hasil wawancara yang dilakukan kesiapan fisik siswa dalam pembelajaran daring diperoleh informasi bahwa siswa merasa kewalahan dan siswa tidak siap secara fisik dalam pembelajaran daring. Bayaknya tugas, kendala jaringan dan juga dalam pembelajaran terkadang membutuhkan waktu berjam-jam karena pembelajaran daring fleksibel membuat para siswa mudah lelah dan bahwa ada siswa yang sakit. Kemudian hasil wawancara yang dilakukan dengan salah satu guru matematika di SMP Sirandorung di Desa Simpang Tiga Laebingke Kecamatan Sirandorung diperoleh informasi bahwa dalam pembelajaran daring kendala tugas-tugas yang diberikan kepada siswa jadi menumpuk jadi memungkin mereka lelah secara fisik. Para guru juga terkadang merasa lelah apalagi kita kadang udah mengajar berjam-jam berapa kelas kemudian sore misalnya ada lagi yang bertanya yang kurang paham atau bahkan bertanya apa tugas karena kita tidak bisa memastikan semua siswa bisa online secara bersamaan. Sehingga kendala ini menyebabkan secara fisik siswa lelah dan tidak siap dalam pembelajaran daring. Jauh lebih disukai oleh anak-anak pembelajaran secara online. Hasil observasi yang dilakukan juga menunjukkan bahwa banyaknya tugas dan terkadang dusahnya mendapatkan jaringan yang bagus dalam pembelajaran menyebabkan siswa jadi lelah dalam belajar secara daring. Kemudian berada di depan layar dalam belajar daring memungkinkan juga menjadikan siswa menjadi lelah dalam mengikuti pembelajaran sehingga keadaan ini dikhawatirkan mempengaruhi hasil belajar siswa. Hal ini sejalan dengan pendapat Djamarah (2008: 114) menyatakan bahwa "Kesiapan fisik berpengaruh pada hasil belajar dan penyesuaian sosial individu. Individu yang kurang sehat mungkin kurangnya vitamin, badanya kurang energi untuk belajar. Hal ini dapat mempengaruhi pada kelancaran proses belajar. Begitupun sebaliknya jika badan tidak sakit (jauh dari gangguan lesu mengantuk, dan sebagainya). Hal ini akan memudahkan untuk belajar karena tidak ada gangguan dari kondisi fisiknya."

\section{Kesiapan Psikis}


Kesiapan psikis siswa dalam pembelajaran daring menunjukkan bagaimana kesiapan siswa secara mental dalam melaksanakan kegiatan pembelajaran secara daring. Sesuai dengan hasil wawancara yang dilakukan dengan beberapa siswa diketahui bahwa siswa merasa pembelajaran daring tidak diminati oleh siswa karena pembelajaran daring tugas-tugas siswa sangat banyak. Selain itu pembelajaran daring menjadikan motivasi belajar siswa rendah karena ketidaksiapan siswa secara psikis dalam pembelajaran.

Kesiapan psikis memberikan andil kepada siswa dalam proses pembelajaran hal ini sejalan dengan pendapat Indriastuti (2017:42) menyatakan bahwa "Kesiapan psikis dalam belajar memberikan andil yang cukup penting bagi peserta didik dalam menjalani pembelajaran di sekolah sehingga memudahkan siswa dalam menguasai bahan pelajaran yang disajikan secara mudah dan efektif".

Berdasarkan pernyataan di atas menunjukkan bahwa dalam pembelajaran secara daring siswa kurang berminat dan kurang termotivasi hal ini mendorong peneliti melihat atau mengobservasi kegiatan pembelajaran siswa secara daring. Kegiatan observasi dilaksanakan pada tanggal 26 Februari 2021 di desa Sirandorung di Desa Simpang Tiga Laebingke Kecamatan diketahui pembelajaran secara daring dilaksanakan beberapa siswa kelas VII namun terlihat siswa kurang antusias dalam pembelajaran daring dikarenakan banyaknya kendala yang mereka hadapi seperti kualitas jaringan yang terkadang tidak mendukung. Siswa terlihat kurang berminat dan kurang bersemangat dalam pembelajaran yang dilaksanakan secara daring. Setiap kegiatan pembelajaran yang dilaksanakan pada umumnya akan dipengaruhi oleh beberapa faktor. Begitu juga pelaksanaan pembelajaran daring yang terbilang masih baru bagi sebagian siswa terlebih siswa kelas VII. Keterbatasan jaringan internet karena sebagian tempat tinggal siswa ada yang tidak mendapatkan jaringan internet yang bagus. Kemampuan siswa dimana sebagian siswa masih kewalahan menggunakan aplikasi pembelajaran di internet. Kualitas jaringan dimana pada saat melakukan video konferensi pembelajaran terkadang suaranya putus-putus diakibatkan kondisi kualitas jaringan terkadang menurun apalagi pada saat kondisi hujan dan di jam-jam sibuk. Kondisi listrik dimana jika terjadi pemadaman listrik sehingga pembelajaran akan terhenti. Faktor waktu dimana pembelajaran online ini lebih melelahkan karena tidak ada batasan waktu terkadang pembelajaran sudah berakhir masih ada beberapa siswa yang bertanya melalui grub WA. Kemudian Paket data selama pembelajaran daring paket data kuota sangat dibutuhkan baik guru maupun siswa. Pada akhirnya menjadikan hasrat untuk beljar dari siswa berkurang.

Pada dasarnya pelaksanaan pembelajaran daring menjadikan pembelajaran lebih efektif dimana guru bisa menggunakan fasilitas internet dalam pembelajaran. Namun terkadang masih mengalami beberapa kendala seperti yang dialami oleh beberapa siswa di Desa Simpang Tiga Laebingke Kecamatan Sirandorung. Dengan demikian dapat disimpulkan bahwa pelaksanaan pembelajaran daring di Desa Simpang Tiga Laebingke Kecamatan Sirandorung siswa mayoritas tidak memiliki kesiapan psikis dalam pelaksanaannya. Hal ini sesuai dengan penelitian Dosmika,dkk (2020) yang menyatakan bahwa psikis seseorang sangat perlu dalam belajar daring.

\section{Kesiapan Materil}

Selain dari kesiapan fisik atau juga kesiapan psikis aspek lain yang turut mempengaruhi siswa dalam pembelajaran daring adalah kesiapan materiil. Kesiapan materiil artinya siswa memiliki kemampuan materil dalam belajar. Kesiapan materiil meliputi adanya bahan yang dipelajari atau dikerjakan baik itu berupa buku bacaan, cataan, buku paket, LKS dan lain-lain.

Pelaksanaan pembelajaran secara daring memang memerlukan berbagai peralatan elektronik, listrik dan juga paket data. Pembelajaran daring ini menyebabkan beberapa orang tua kewalahan dalam memenuhi berbagai fasilitas anak-anak dalam belajar. Selain itu pada dasarnya orang tua juga harus bisa mengawasi anak-anaknya dalam belajar. Hal ini ditujukan agar pembelajaran berjalan lancar dan anak-anak tidak main-main dalam belajar dari rumah.

Pada dasarnya pelaksanaan pembelajaran daring menjadikan pembelajaran lebih efektif dimana guru bisa menggunakan fasilitas internet dalam pembelajaran. Namun terkadang masih mengalami beberapa kendala seperti yang dialami oleh beberapa siswa di Desa Simpang Tiga Laebingke Kecamatan Sirandorung. Dengan demikian dapat disimpulkan bahwa pelaksanaan pembelajaran daring di Desa Simpang Tiga Laebingke Kecamatan Sirandorung siswa mayoritas tidak memiliki kesiapan psikis dalam pelaksanaannya.

Berdasarkan hasil wawancara yang dilakukan diketahui ada beberapa kendala yang dihadapi oleh siswa, orang tua siswa atau juga guru dalam melaksanakan pembelajaran daring 
seperti kendala pada kualitas jaringan, kendala listrik yang sering padam dan kendala kuota internet. Berdasarkan hasil observasi yang dilakukan pada tanggal 1 Maret 2021 pelaksanaan pembelajaran daring mengalami beberapa kendala seperti kendala jangkauan jaringan internet dimana ada beberapa siswa kelas VII lokasi rumahnya tidak memiliki jaringan internet sehingga terkadang mereka harus berjalan kaki ke desa tetangganya. Selain itu, ada sebagian siswa yang mengantarkan tugasnya langsung ke sekolah tetapi menggunakan pakaian biasa dan memakai masker. Berdasarkan hasil wawancara yang dilakukan diketahui bahwa terdapat beberapa kendala yang dihadapi guru maupun siswa dalam pembelajaran daring pada masa pandemi ini.Beberapa faktor tersebut seperti faktor kualitas jaringan sehingga menyebabkan pembelajaran kurang lancar, faktor kemampuan guru menggunakan aplikasi pembelajaran di internet. Faktor keterbatasan jaringan internet di beberapa tempat tinggal siswa, kondisi listrik dimana jika terjadi pemadaman listrik sehingga pembelajaran daring akan terhenti dan siswa tidak bisa mengirim tugas pada guru. Faktor waktu yang cukup flexible dimana pembelajaran online ini lebih melelahkan karena tidak ada batasan waktu terkadang pembelajaran sudah berakhir masih ada beberapa siswa yang bertanya melalui grub WA. Kemudian faktor kendala paket data selama pembelajaran daring paket data kuota sangat dibutuhkan baik guru maupun siswa. Hal ini sejalan dengan penelitian Dosmuika, dkk (2020) yang menyatakan kesiapan materiil atau perlengkapan untuk daring sebagai penunjang dalam belajar daring memang sangat penting peranannya.

\section{KESIMPULAN}

Berdasarkan analisis data yang dilakukan diperoleh dengan teknik analisis data, maka penelitian ini dapat disimpulkan berdasarkan hasil penelitian yang dilakukan diketahui bahwa nilai rata-rata angket sebesar sebesar 65.33 dengan kategori kurang. Pencapaian nilai rata-rata ini menggambarkan bahwa kesiapan siswa dalam pembelajaran daring masih kurang. Sesuai dengan hasil wawancara yang dilakukan kesiapan fisik siswa dalam pembelajaran daring diperoleh informasi bahwa siswa merasa kewalahan dan siswa tidak siap secara fisik dalam pembelajaran daring. Siswa tidak memiliki kesiapan secara psikmis dalam pembelajaran daring. Dari hasil wawancara diperoleh informasi bahwa siswa merasa pembelajaran daring tidak diminati oleh siswa karena pembelajaran daring tugas-tugas siswa sangat banyak. Selain itu pembelajaran daring menjadikan motivasi belajar siswa rendah karena ketidaksiapan siswa secara psikis dalam pembelajaran. Hasil wawancara dengan beberapa siswa kelas VII di desa Simpang Tiga Laebingke Kecamatan Sirandorung diketahui keluarga siswa kewalahan terhadap kesiapan materiil dalam pelaksanaan pembelajaran daring. Orang tua siswa yang mayoritas juga petani menjadi kewalahan saat memenuhi berbagai fasilita siswa dalam belajar secara daring.

\section{Saran}

Berdasarkan kesimpulan dan implikasi hasil penelitian di atas maka adapun yang menjadi saran penulis yaitu kepada orangtua diharapkan dapat membimbing anak sesuai kebutuhan anak dalam pembelajaran daring. Orang tua diharapkan dapat menyediakan fasilitas dan menyediakan waktu untuk memberikan pendampingan serta bimbingan kepada anak. Kepada guru diharapkan dapat memantau serta dapat melakukan kerja sama bersama orang tua dengan baik. Sehingga tujuan dalam pembelajaran dapat tercapai meskipun dilaksanakan secara daring. Kepada siswa diharapkan memiliki semangat dan mampu mengikuti pembelajaran daring dengan baik agar tetap dapat mencapai hasil belajar yang maksimal. Kepada kepala desa Simpang Tiga Laebingke dan pemerintah diharapkan solusi yang sangat tepat dan efektif terhadap permasalahan pembelajaran daring selama masa pandemic seperti penyediaan kuota internet belajar bagi siswa dan guru.

\section{REFERENSI}

Dimyati dan Mudjiono, 2009. Belajardan Pembelajaran, Jakarta: Rineka Cipta.

Djamarah dan Zain. 2008. Strategi Belajar. Jakarta: Rineka Cipta.

Effendi. Hubungan Readiness (Kesiapan) Belajar Siswa Dengan Hasil Belajar Fisika Siswa Kelas X SMK Muhammadiyah 03 Sukaraja. Jurnal Pendidikan Fisika: JPF. Volume 5 Nomor 1.

Faridatur Rohmah, 2016, “Analisis Kesiapan Sekolah Terhadap Penerapan Pembelajaran Online (E-Learning) di SMA Negeri 1 Kutowinangun”.

Indriastuti, Ambar. 2017. Pengaruh Kesiapan Belajar Siswa Dan Keterampilan Mengajar Guru Terhadap Hasil Belajar. Jurnal Informasi Dan Komunikasi Administrasi Perkantoran. Volume 1 Nomor 1. 
JURNAL MathEdu (Mathematic Education Journal) http://journal.ipts.ac.id/index.php/MathEdu Vol. 4 No. 2 Juli 2021

Kemendikbud. 2020. Surat edaran pelaksanaan kebijakan pendidikan dalam masa darurat penyebaran coronavirus Disease (covid- 19). Diakses 23 November 2020, dari https://jdih.kemdikbud.go.id/arsip/SE\%20Menteri.

Laksmi, Dewi. 2017. Rancangan Program Pembelajaran Daring Di Perguruan Tinggi: Studi Kasus Pada Mata Kuliah Kurikulum Pem-Belajar Di Universitas Pendidikan Indonesia. Jurnal Edutech, Vol.16, No.2, Juni 2017.

Mulyani. Dessy. 2013. Hubungan Kesiapan Belajar Siswa Dengan Prestasi Belajar. Jurnal Ilmiah Konseling: Konselor. Volume 2 Nomor 1.

Pribadi, Benny A. 2009. Model Desain Sistem Pembelajaran. Jakarta: Dian Rakyat.

Riyanto, Yatim. 2009. Paradigm Baru Pembelajaran. Jakarta: Kencana.

Rohani, Ahmad, Pengelolaan Pengajaran Sebuah Pengantar Menuju Guru Profesional, Jakarta: Rineka Cipta, 2010.

Simanjuntak, D. R., Ritonga, M. N., \& Harahap, M. S. (2020). ANALISIS KESULITAN BELAJAR SISWA MELAKSANAKAN PEMBELAJARAN SECARA DARING SELAMA MASA PANDEMI COVID-19 Oleh. Mathematic Education Journal)MathEdu, 3(3), 142146. http://journal.ipts.ac.id/index.php/

Slameto. 2012. Belajar dan Faktor-Faktor yang Mempengaruhinya. Jakarta: Rineka Cipta.

Susanto, Ahmad. 2013. Teori belajar dan Pembelajaran di Sekolah Dasar. Jakarta: Rineka Cipta.

Syah, Muhibbin. 2011. Psikologi Pendidikan dengan Pendekatan Baru, Bandung: Remaja Rosda Karya.

Jamal Syamsul, 2020, dengan judul penelitian "Analisis Kesiapan Pembelajaran E-Learning Saat Pandemi Covid-19 di SMK Negeri 1 Tambelangan."

Wahyu. 2020. Dampak Covid-19 Terhadap Implementasi Pembelajaran Daring Di Sekolah Dasar. Edukatif : Jurnal Ilmu Pendidikan Vol 2 No 1 April.

Warsita, Bambang. 2008. Teknologi Pembelajaran Landasan dan Aplikasi. Jakarta: Rineka Cipta. 